\title{
PENENTUAN PENURUNAN TEGANGAN BERDASARKAN MINIMUM SPANNING TREE PADA JARINGAN LISTRIK DISTRIBUSI PRIMER
}

\author{
Hardianto \\ Program Studi Teknik Elektro, STITEK Bontang \\ e-mail: Hard_yan@yahoo.com
}

\begin{abstract}
ABSTRAKSI
Determination of the minimum spanning tree is widely used to solve optimization problems are problems that demand solutions minmum search. In the electricity distribution network, the minimum spanning tree (MST) is used to find the minimum cable length for the system to the power grid becomes more optimal. The use of a minimum weight minimum cable length can be used as a variable for calculating the voltage drop (voltage drop) of an electricity distribution network. The method used in this research is the process of field observations and data processing. Field observations aims to take some of the coordinates of each pole on the electricity distribution network. While the data processing is done to create a geographic information system that is based on primary data in the form of a power pole coordinates data and secondary data along with the data in the form of electricity distribution networks. Furthermore, the results obtained by the minimum weight of the MST combined with existing data on the electricity distribution networks like cable cross-sectional area, the type of cable used, and the current through the tissue with voltage measurement results from the ends of the network to obtain results penurungan voltage (voltage drop) resulting from each feeder. Results (voltage drop) can be used as a basis for evaluating the electrical distribution network that has been existing, particularly in the City Bontang.
\end{abstract}

Keywords: minimum spanning tree, MST algorithm, voltage drop, graph

\section{PENDAHULUAN}

Pada saat ini, algoritma telah banyak digunakan di berbagai aplikasi salah satunya di bidang jaringan listrik. Penggunaan algortima disesuaikan atas kebutuhan dan ketepatan implementasi di lapangan. Algoritma dibagi berdasarkan optimasi yang dihasilkannya, antara lain algoritma yang mencari lintasan terpendek dari suatu simpul ke simpul lain dalam sebuah graf berbobot dan algoritma yang mencari minimum spanning tree (pencarian pohon rentang minimum) yaitu lintasan pada graf berbobot dengan jumlah bobot yang paling kecil.

Penggunaan peta dalam penerapan graf berbobot dapat dilakukan pada sistem informasi geografis (SIG). Sistem informasi geografis adalah sistem basis data yang bersifat sapsial. Pemanfaatan SIG memberikan kemudahan bagi pengguna maupun pengambil keputusan dalam menentukan kebijakan yang diambil, khususnya kebijakan yang berkaitan dengan aspek spasial. Hal ini dimungkinkan karena kemampuan SIG untuk memproses dan menganalisis data dengan cepat dan dapat dipresentasikan dalam format geografis.

Penggunaan MST (minimum spanning tree) pada jaringan distribusi listrik diharapakan mampu menghasilkan rentangan jaringan kabel listrik yang menghubungkan beberapa jumlah lokasi menggunakan panjang kabel yang sependek-pendeknya. Dalam membentuk suatu jaringan distribusi listrik perlu mempertimbangkan faktor penggunaan biaya yang efesien. Biaya berkaitan erat dengan penggunaaan panjang kabel listrik, selain penggunaan tiang listrik dan trafo distribusi yang dibutuhkan. Panjang pendeknya penggunaan kabel listrik suatu jaringan distribusi listrik akan memperngaruhi biaya investasi, pemeliharaan dan perbaikan suatu jaringan listrik.

Disamping itu, penggunaan kabel listrik yang terlalu panjang pada jaringan distribusi listrik akan mempengaruhi kualitas tegangan pelayanan dan kualitas keandalan jaringan listrik. Kualitas tegangan pelayanan dipengaruhi oleh besar kecilnya penurunan tegangan yang ditimbulkan pada ujung-ujung kabel jaringan listrik tersebut. Sedangkan kualitas keandalan listrik dipengaruhi oleh intensitas dan lamanya pemadaman listrik yang terjadi.

Saat ini, jaringan listrik distribusi primer $20 \mathrm{kV}$ yang ada di Kota Bontang menggunakan sistem radial yang berarti penggunaan kabel jaringan listrik untuk mencapai pelanggan listrik diseluruh wilayah Kota Bontang hanya 
satu arah saja dan akan menjadi lebih panjang. Dampaknya, pada saat terjadi gangguan pada sistem jaringan listrik distibusi primer maka banyak pelanggan listrik mengalami pemadaman listrik

Secara teori, penurunan tegangan pada jaringan distribusi listrik secara umum berbanding lurus dengan panjang kabel listrik yang digunakan dan beban listrik serta berbanding terbalik dengan luas penampang penghantar (Johnson, D. 1992). Sesuai dengan standar tegangan yang ditentukan oleh PT. PLN (SPLN), perancangan jaringan distribusi listrik dibuat agar penurunan tegangan di ujung penerima maksimal $10 \%$ dari tegangan sumber lsitrik.

Atas dasar keterkaitan antara panjang penghantar (kabel listrik) terhadap penurunan tegangan suatu jaringan distibusi listrik, maka dibuatlah penelitian dengan mengaplikasian minimum spanning tree pada jaringan distribusi listrik untuk wilayah Kalimantan Timur khususnya di wilayah Kota Bontang. Jaringan distribusi listrik yang digunakan pada penelitian ini hanya jaringan distribusi primer (jaringan tegangan menengah) yaitu jaringan distribusi listrik yang memiliki tegangan $20 \mathrm{kV}$. Adapun algoritma yang digunakan untuk mendapatkan minimum spanning tree adalah algoritma MST.

Hal ini dimaksudkan untuk mengetahui besarnya penurunan tegangan yang terjadi pada jaringan listrik tegangan primer di wilayah Kota Bontang akibat diperolehnya panjang kabel yang optimal dari sistem, selain sebagai untuk pemerataan pemenuhan jaringan listrik bagi penduduk di wilayah Kota Bontang. Diharapkan dengan pemanfaatan algoritma MST (minimum spanning tree), perancangan jaringan distribusi listrik di wilayah Kota Bontang dapat lebih optimal.

Penurunan Tegangan (Drop Voltage)

Penurunan tegangan merupakan besarnya tegangan yang hilang pada suatu penghantar. Penurunan tegangan pada saluran tenaga listrik secara umum berbanding lurus dengan panjang saluran dan beban serta berbanding terbalik dengan luas penampang penghantar. Besarnya Penurunan tegangan dinyatakan baik dalam persen atau besaran Volt. Besarnya batas atas dan bawah ditentukan oleh kebijaksanaan perusahaan kelistrikan. Perhitungan penurunan tegangan praktis pada batas tertentu dengan hanya menghitung besarnya tahanan masih dapat dipertimbangkan, namun pada sistem jaringan khususnya pada sistem tegangan menengah masalah indukstansi dan kapasitansinya diperhitungkan karena nilainya cukup berarti (PT.PLN (Persero), 2010: hal 20).

Penurunan tegangan ditimbulkan oleh arus yang mengalir melalui tahanan kawat. Penurunan tegangan $\mathrm{V}$ pada penghantar semakin besar jika arus I pada penghantar semakin besar dan jika tahanan penghantar $\mathrm{R}$ dan $\ell$ semakin besar pula. Penurunan tegangan merupakan penanggung jawab terjadinya kerugian pada penghantar karena dapat menurunkan tegangan pada beban. Akibatnya hingga berada di bawah tegangan nominal yang dibutuhkan. Atas dasar hal tersebut maka penurunan tegangan yang diijinkan untuk instalasi arus kuat hingga $1.000 \mathrm{~V}$ yang ditetapkan dalam persen dari tegangan kerjanya (Daryanto,2010: hal 18 \& 42). Grafik toleransi tegangan pelayanan yang diijinkan ditunjukkan pada gambar 1.

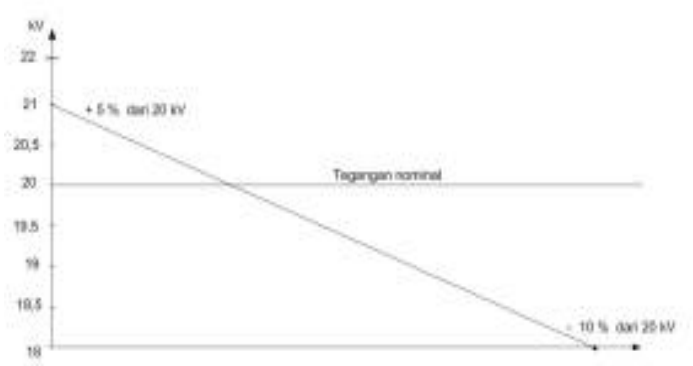

Gambar 1. Toleransi tegangan pelayanan yang dijinkan.

(Sumber: standar perusahaan listrik negara (SPLN)

Sesuai dengan standar tengangan yang ditentukan oleh PLN (SPLN), perancangan jaringan dibuat agar jatuh tegangan di ujung diterima $10 \%$. Penurunan tegangan pada jaringan disebabkan adanya rugi tegangan akibat hambatan listrik (R) dan reaktansi (X). Penurunan tegangan phasor $\mathrm{Vd}$ 
pada suatu penghantar yang mempunyai impedansi (Z) dan membawa arus (I) dapat dijabarkan sesuai persamaan 1 .

$\mathrm{Vd}=\mathrm{I} . \mathrm{Z}$

Pembahasan ini yang dimaksudkan dengan Penurunan tegangan $(\Delta \mathrm{V})$ adalah selisih antara tegangan kirim $(V k)$ dengan tegangan terima $\left(V_{T}\right)$, maka Penurunan tegangan ditunjukkan pada persamaan 2 .

$$
\Delta V=(V k)-\left(V_{T}\right)
$$

Adanya resistansi pada penghantar maka tegangan yang diterima konsumen (Vr) akan lebih kecil dari tegangan kirim (Vs), sehingga Penurunan tegangan (Vdrop) merupakan selisih antara tegangan pada pangkal pengiriman (sending end) dan tegangan pada ujung penerimaan (receiving end) tenaga listrik. Penurunan tegangan relatif dinamakan regulasi tegangan $\mathrm{V}_{\mathrm{R}}$ (voltage regulation) dan dinyatakan oleh persamaan 3 .

$$
V_{R}=\frac{V_{s}-V_{r}}{V_{r}} x 100 \%
$$

Keterangan :

$\mathrm{Vs}=$ tegangan pada pangkal pengiriman

$\mathrm{Vr}=$ tegangan pada ujung penerimaan

Untuk menghitung penurunan tegangan, diperhitungkan reaktansinya, maupun faktor dayanya yang tidak sama dengan satu. Penyederhanaan perhitungan, diasumsikan beban-bebannya merupakan beban fasa tiga yang seimbang dan faktor dayanya $(\operatorname{Cos} \varphi)$ antara $0,6 \mathrm{~s} / \mathrm{d} 0,85$. tegangan dapat dihitung berdasarkan rumus pendekatan hubungan sebagai berikut :

$(\Delta V)=\mathrm{I}(\mathrm{R} \cdot \cos \varphi+\mathrm{X} \cdot \sin \varphi) \mathrm{L}$ (4) dengan :

$$
\begin{aligned}
& I=\text { Arus beban (Ampere ) } \\
& R=\text { Tahanan rangkaian (Ohm ) } \\
& X=\text { Reaktansi rangkaian (Ohm) }
\end{aligned}
$$

Hambatan listrik pada penghantar dipengaruhi oleh 3 faktor yaitu panjang, luas penampang dan jenis bahan. Hambatan berbanding lurus dengan panjang benda, semakin panjang maka semakin besar hambatan suatu benda. Hambatan juga berbanding terbalik dengan luas penampang benda, semakin luas penampangnya maka semakin kecil hambatannya.. Hambatan juga berbanding lurus dengan jenis benda (hambatan jenis) semakin besar hambatan jenisnya maka semakin besar hambatan benda itu. Secara matematika dapat dituliskan :

$$
\mathrm{R}=\rho . \mathrm{L} / \mathrm{A}
$$

dengan:

$\rho=$ hambatan jenis $(\mathrm{ohm} / \mathrm{m})$

$\mathrm{L}=$ adalah panjang benda $(\mathrm{m})$

$\mathrm{A}=$ adalah luas penampang ( $\mathrm{m}$ kuadrat) biasanya luas penampang bentuknya lingkaran.

\section{METODE PENELITIAN}

\subsection{Bahan Penelitian}

Data yang dikumpulkan dalam penelitian ini digunakan untuk menjawab pertanyaan penelitian yang telah dirumuskan, karena data yang diperoleh akan dijadikan landasan dalam mengambil kesimpulan. Adapun metode pengumpulan data yang digunakan dalam penelitian ini, antara lain:

1. Studi literatur, yaitu penelusuran literatur mengenai dasar pengetahuan tentang halhal yang berkaitan dengan penelitian ini. Metode ini dilakukan dengan cara mencari buku-buku, artikel-artikel, dan jurnal-jurnal ilmiah mengenai algoritma yang merupakan salah satu cabang ilmu komputer, khususnya mengenai graf, minimum spanning tree, dan algortima MST. Selain itu juga dilakukan penelusuran tentang data spasial yang ada pada sistem informasi geografis (SIG) serta hal-hal yang berkaitan dengan penurunan tegangan (drop voltage) pada suatu jaringan distribusi listrik.

2. Pengumpulan data jaringan distribusi listrik yang diperoleh dari PT. PLN (Persero) Area Bontang. Data yang diperoleh adalah data single line diagram jaringan listrik distribusi primer $20 \mathrm{kV}$ (jaringan tegangan menengah) dengan beberapa penyulang (feeder) di wilayah kerja PT. PLN (persero) Area Bontang. Selain itu juga diperoleh data yang berkitan langsung terhadap penurunan tegangan (drop voltage) pada jaringan distribusi listrik berupa tegangan pada masing-masing ujung penyulang (feeder), data trafo distribusi, serta data jenis penghantar kabel yang digunakan pada jaringan listrik distribusi primer $20 \mathrm{kV}$. 
3. Pengumpulan data peta administratif wilayah Kota Bontang yang diperoleh dari Badan Perencanaan dan Pembangunan Daerah (Bappeda) Kota Bontang. Data yang digunakan adalah data luas wilayah, serta beberapa data sungai dan jalan. Metode pengambilan data peta menggunakan metode fotogrametri (foto udara) dan divalidasi dengan oleh Bakosurtanal (Badan koordinasi survey dan pemetaan nasional).

4. Melakukan pengamatan secara langsung pada jaringan listrik distribusi primer $20 \mathrm{kV}$ yang di wilayah Kota Bontang untuk disesuaikan dengan data yang diperoleh dari PT. PLN (Persero) Area Bontang serta data dari Bappeda Kota Bontang, sehingga diperoleh panjang kabel listrik pada jaringan listrik distribusi primer $20 \mathrm{kV}$ yang mendekati kenyataan.

2.2 Alat Penelitian

Alat-alat yang digunakan dalam penelitian ini adalah:

1. Perangkat keras (hardware)

a. Komputer dengan prosesor Intel Core 2 CPU T5500 1,66GHz.

b. Memori 1,50 GB RAM.

c. Hard disk 80 GB.

d. Monitor 14,1'inchi.

e. Printer.

f. Scanner.

2. Perangkat lunak (software)

a. Sistem operasi Microsoft Windows XP.

b. MapInfo Versi 8

c. ArcView GIS versi 3.3.

d. Microsoft Office 2007.

e. Microsoft Visio 2003.

2.3 Perancangan Sistem

Penilitian ini, terdapat perancangan yang akan dilakukan, antara lain:

a. Diagram Konteks

Pembuatan suatu diagram konteks, terlebih dahulu menganalisa sistem yang akan dibuat berupa informasi dan data apa saja yang dibutuhkan. Selanjutnya menentukan sumber data yang dibutuhkan sistem dan tujuan informasi yang dihasilkan oleh sistem. Setelah berhasil mendeskripsikan kebutuhan data dan informasi yang harus dihasilkan, lalu menggambarkan aliran anak panah untuk mewakili data berupa informasi tersebut. Dari analisa yang dilakukan, maka diperoleh diagram konteks dari penentuan jalur minimun menggunakan MST dengan studi kasus jaringan listrik distribusi primer $20 \mathrm{kV}$ yang di wilayah Kota Bontang dapat dijelaskan pada gambar 2 .

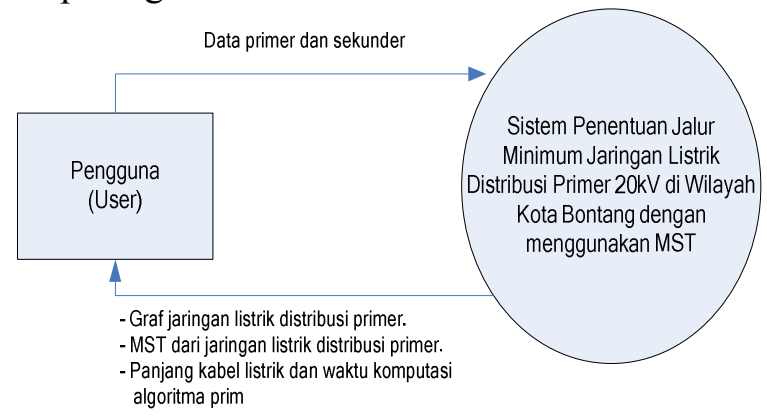

Gambar 2 Diagram konteks penentuan jalur minimum

Berdasarkan gambar 2, pengguna (user) pada sistem ini memasukkan data sekunder berupa data peta adminitratif wilayah Kota Bontang, antara lain; data jalan, dan data sungai. Selain itu juga user memasukkan data primer berupa data jaringan listrik distribusi primer $20 \mathrm{kV}$, antara lain; data tiang listrik distribusi primer, data saluran udara tegangan menengah (SUTM) pada masing-masing penyulang (feeder), data gardu distribusi, data LBS (load breaker switch), serta data jarak antara tiang listrik distribusi primer, antara gardu distribusi, atau antara LBS. Selanjutnya sistem ini dapat menampilkan model graf jaringan listrik distribusi primer $20 \mathrm{kV}$, menampilkan hasil jalur minimum jaringan listrik distribusi primer $20 \mathrm{kV}$, urutan rute kabel yang melewati tiang-tiang listrik distribusi, menghasilkan waktu komputasi dalam pencarian jalur minimum jaringan listrik distribusi primer, serta menampilkan grafik hasil pengujian MST.

b. Diagram Alir Data

DAD menggambarkan penyimpanan data dan proses yang mentransformasikan data. DAD menunjukkan hubungan antara data pada sistem dan proses yang mengikutinya. 
Adapun DAD pada sistem penentuan jalur minimum jaringan distribusi listrik menggunakan minimum spanning tree dengan studi kasus jaringan listrik distribusi primer $20 \mathrm{kV}$ di wilayah Kota Bontang dapat dijelaskan pada gambar 3 dalam bentuk DAD level 0;

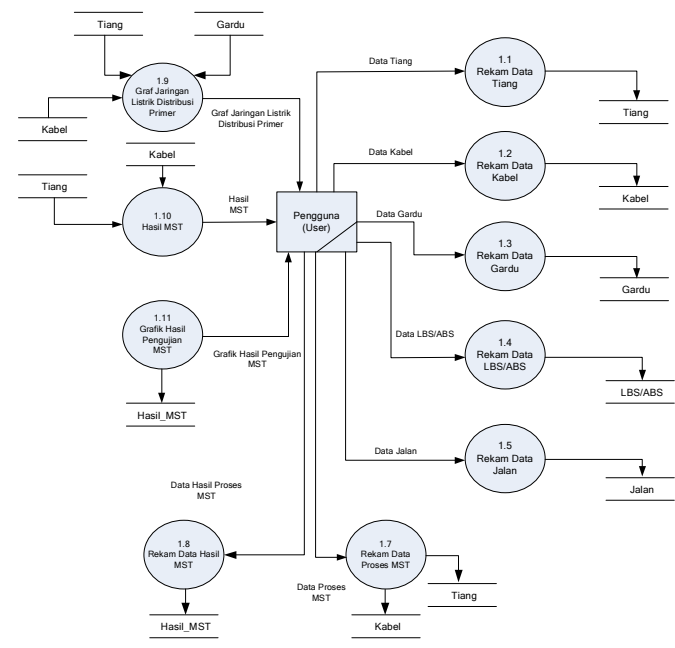

Gambar 3 Diagram alir data level 0 pada sistem MST

Secara garis besar, gambar 3 memiliki beberapa proses dalam diagram alir data (DAD) level 0 pada sistem algoritma MST dengan menggunakan program ArcView GIS 3.3. Terdapat beberapa proses yang terjadi pada gambar 3, yang meliputi;

1. Proses rekam data tiang listrik distribusi.

2. Proses rekam data kabel SUTM.

3. Proses rekam data gardu distribusi.

4. Proses rekam data LBS/ABS.

5. Proses rekam data jalan.

6. Proses rekam data untuk penentuan jalur minimum dengan MST.

7. Proses rekam data hasil penentuan jalur minimum pada MST.

8. Proses menampilkan graf jaringan listrik distribusi primer.

9. Proses menampilkan jalur minimum dari MST.

10. Proses menampilkan grafik hasil pengujian MST.

c. Relasi Antar Tabel

Pada prinsipnya perancangan basis data untuk sistem penentuan jalur minimum jaringan listrik distribusi primer $20 \mathrm{kV}$ menggunakan MST dengan studi kasus pada jaringan listrik distribusi primer $20 \mathrm{kVKota}$ Bontang menggunakan basis data pada program ArcView GIS 3.3. Program yang dibangun dengan ArcView GIS 3.3 tersebut menggunakan beberapa tabel pada basis datanya, diantaranya tabel tiang, tabel kabel, tabel gardu, tabel LBS/ABS, dan tabel jalan. Relasi antar tabel-tabel tersebut diperlihatkan pada gambar 4.

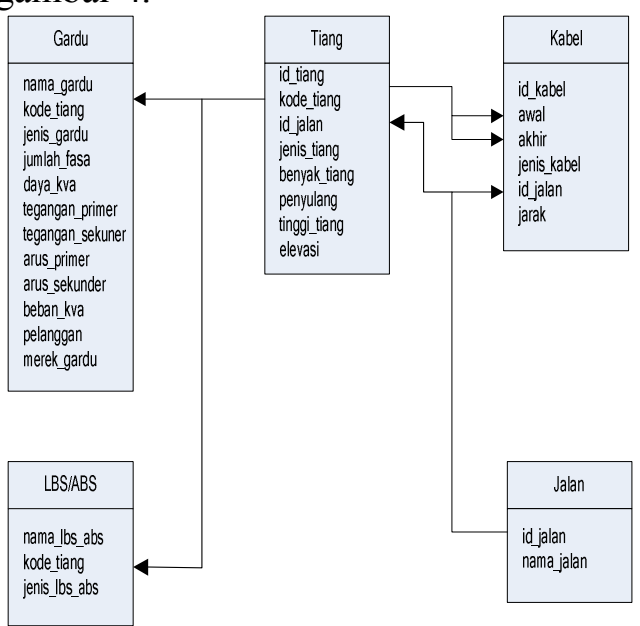

Gambar 4 Relasi antar tabel dalam MST 2.4 Tahapan Penelitian

Penelitian ini dilakukan dengan melalui tahapan-tahapan sebagai berikut:

1. Melakukan pengamatan dan pengumpulan data jaringan listrik distribusi primer $20 \mathrm{kV}$ pada PT. PLN (Persero) Area Bontang serta data peta administratif wilayah Kota Bontang.

2. Instalasi program-program yang dibutuhkan serta pengaturannya.

3. Melakukan persiapan data yang telah ada sehingga dapat digunakan oleh program aplikasi.

4. Merancang model graf jaringan listrik distribusi primer $20 \mathrm{kV}$ sesuai dengan data yang diperoleh, kemudian dari graf tersebut diberi masukan data yang dibutuhkan untuk mencari bobot minimum suatu graf dari masing-masing tiang listrik yang telah disesuaikan dengan data peta administratif Kota Bontang dengan menggunakan program ArcView GIS 3.3

5. Dengan menggunakan algoritma MST ditentukan minimum spanning tree dari model graf pada jaringan distribusi listrik primer 20kV. Selanjutnya dilakukan 
perhitungan dan simulasi oleh program ArcView GIS 3.3 untuk mendapatkan jalur minimum dari jaringan listrik distribusi primer $20 \mathrm{kV}$ di wilayah Kota Bontang.

6. Perhitungan penurunan tegangan (drop voltage) yang terjadi pada jaringan listrik distribusi primer $20 \mathrm{kV}$ berdasarkan data hasil panjang minimum kabel yang dihasilkan dari proses minimum spanning tree (MST). Perhitungan dilakukan untu masing-masing penyulang (feeder) yang ada pada jaringan listrik distribusi primer $20 \mathrm{kV}$ di Wilayah area Kota Bontang.

7. Membuat analisa terhadap hasil yang diperoleh dari perhitungan penurunan tegangan (drop voltage) dan panjang minimum kabel listrik dari algoritma MST.

8. Langkah terakhir menarik kesimpulan dari hasil analisa yang telah dilakukan tersebut.

Tahapan-tahapan penelitian ini ditunjukkan pada gambar 5 .

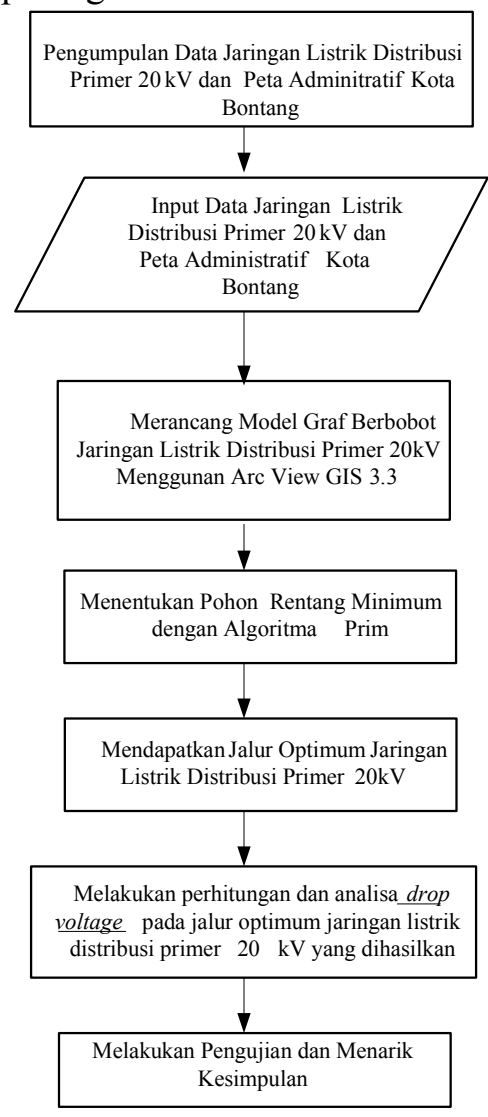

Gambar 5. Bagan tahapan penelitian
2.5 Tahapan Proses Penentuan Pohon Rentang Minimum

Data yang diperoleh dari PT. PLN (Persero) Area Bontang dan Bappeda Kota Bontang berupa tiang listrik, kabel listrik, gardu distribusi, LBS/ABS, serta nama jalan dimasukkan ke dalam sistem dengan dukungan data peta administratif wilayah Kota Bontang. Semua komponen yang telah disebutkan tersebut, diperlukan untuk mendapatkan model graf jaringan listrik distribusi primer $20 \mathrm{kV}$ yang sesuai dengan kondisi yang ada di lokasi penelitian.

Titik tiang, titik gardu, dan titik LBS/ABS pada jaringan listrik distribusi primer $20 \mathrm{kV}$ tersebut dihubungkan dengan garis yang telah disesuaikan dengan jarak masing-masing untuk kemudian membentuk suatu graf jaringan listrik distribusi primer $20 \mathrm{kV}$. Matriks ketetanggan yang direpresentasikan merupakan graf dengan jarak antar tiang listrik distribusi dan bukan bobot minimumnya.

Bobot minimum diperoleh bersama-sama dengan proses penentuan jalur minimum dengan algoritma MST. Kondisi ini terjadi karena penentuan jalur minimum dengan minimum spanning tree telah disesuaikan dengan kondis wilayah, khususnya di Kota Bontang.

Selanjutnya data-data tersebut diproses menggunakan metode algoritma MST yang telah dimodifikasi untuk mendapatkan hasil berupa jalur minimum suatu jaringan listrik distribusi primer $20 \mathrm{kV}$ di wilayah Kota Bontang dengan disertai total bobot minimum yang dihasilkannya, artinya total panjang kabel listrik yang dipergunakan untuk menghubungkan tiang-tiang listrik distribusi primer $20 \mathrm{kV}$. Selain itu, proses tersebut menghasilkan urutan jalur/rute dan waktu komputasi dalam pencarian jalur minimum tersebut. Tahapan tersebut ditunjukkan dengan flowchart program pada gambar 6 . 

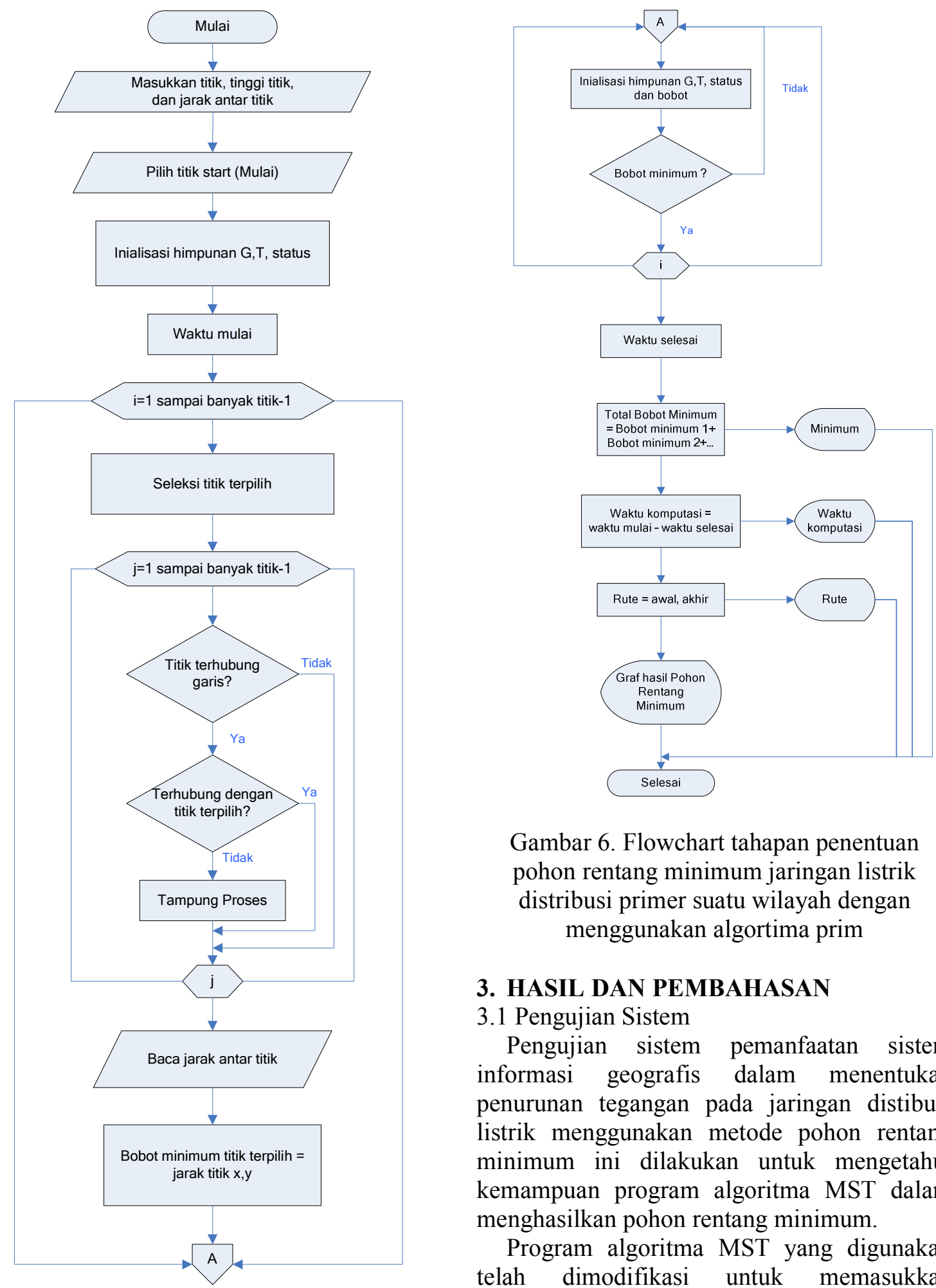

Gambar 6. Flowchart tahapan penentuan pohon rentang minimum jaringan listrik distribusi primer suatu wilayah dengan menggunakan algortima prim

\section{HASIL DAN PEMBAHASAN}

\subsection{Pengujian Sistem}

Pengujian sistem pemanfaatan sistem informasi geografis dalam menentukan penurunan tegangan pada jaringan distibusi listrik menggunakan metode pohon rentang minimum ini dilakukan untuk mengetahui kemampuan program algoritma MST dalam menghasilkan pohon rentang minimum.

Program algoritma MST yang digunakan telah dimodifikasi untuk memasukkan parameter jarak antar tiang listrik distribusi untuk menghasilkan graf dengan bobot minimum.

Penggunaan variasi jumlah simpul, jumlah sisi, dan variasi model graf adalah untuk mendapatkan hasil pengujian berupa 
kemampuan algoritma MST dalam menentukan pohon rentang minimum berdasarkan masukan jarak antar tiang listrik. Pengujian sistem ini juga mengunakan program yang dibuat dengan ArcView GIS 3.3 dengan bantuan script avenue.

Maksud dan tujuan penggunaan program ini adalah membantu menghubungkan data jarak antar tiang listrik distribusi dengan metode algoritma MST untuk mendapatkan pohon rentang minimum suatu graf berbobot dan diimplementasikan dalam jaringan listrik distribusi primer Kota Bontang

\subsection{Pembahasan}

Dari proses pengujian yang telah dilakukan, maka akan diperoleh tiga bagian hasil pengujian. Bagian pertama merupakan hasil pengujian dari pengujian 1 sampai dengan 3, dan bagian kedua merupakan hasil pengujian 4 sampai dengan 5. Untuk bagian ketiga merupakan hasil pengujian 6 .

Hasil pengujian bagian pertama menitikberatkan pada kemampuan sistem dalam menghasilkan MST dengan bobot minimum untuk kondisi yang berbeda-beda. Selain itu juga untuk mengetahui waktu komputasi yang dibutuhkan oleh sistem untuk menentukan pohon rentang minimum. Secara lengkap mengenai hasil pengujian 1 sampai dengan pengujian 3 untuk bobot minimum serta waktu komputasi yang dibutuhkan dapat dilihat pada Tabel 1. berikut:

Berdasarkan Tabel 1. terlihat bahwa waktu komputasi yang diperlukan algoritma minimum spanning tree (MST) dalam menghasilkan bobot minimum mengalami kenaikan seiring dengan pertambahan jumlah simpul dan sisi suatu graf. Penentuan bobot minimum suatu wilayah dengan algoritma MST akan membutuhkan waktu komputasi yang lama dan apabila jika jumlah simpul dan sisi graf ditambah. Hal ini disebabkan karena adanya tambahan script program pada algoritma MST, sehingga penentuan bobot minimum dengan algoritma MST akan mengalami penambahan proses perhitungan untuk menghasikan bobot minimum pada masing-masing graf.
Selanjutnya hasil pengujian bagian kedua menitikberatkan pada kemampuan algoritma MST dalam menghasilkan pohon rentang minimum berupa bobot minimum, yang diimplementasikan kedalam jaringan listrik distribusi primer Kota Bontang yang telah eksisting. Dari pengimplementasiannya, diharapkan diperoleh bobot minimium dari MST jaringan listrik distribusi primer Kota Bontang yang optimal yaitu penggunaan panjang kabel listrik yang minimum berdasarkan kondisi geografis Kota Bontang.

Hasil pengujian bagian kedua merupakan hasil dari pengujian 4 dan pengujian 5 . Pengujian dilakukan di tempat berbeda, yaitu kawasan kelurahan api-api dan kawasan perumahan Bontang KCY. Adapun rincian hasil pengujian 4 dan pengujian 5 dapat dilihat pada tabel 2.:

Tabel 1. Bobot minimum dan waktu komputasi pengujian 1 sampai dengan 3

\begin{tabular}{cccccc} 
N & Peng & \multicolumn{2}{c}{ Jumlah } & Bobot & $\begin{array}{c}\text { Waktu } \\
\text { o }\end{array}$ \\
ujian & $\begin{array}{c}\text { Simp } \\
\text { ul }\end{array}$ & Sisi & $\begin{array}{c}\text { Minimu } \\
\text { m (m) }\end{array}$ & $\begin{array}{c}\text { Kompens } \\
\text { asi (s) }\end{array}$ \\
\hline 1 & I & 20 & 49 & 3218,63 & 23 \\
2 & II & 40 & 104 & 5568,58 & 372 \\
3 & III & 60 & 163 & 8476,34 & 1941 \\
\hline
\end{tabular}

Tabel 2. Hasil pengujian 4 dan 5

\begin{tabular}{cccc}
\hline $\begin{array}{c}\text { Pengu } \\
\text { jian }\end{array}$ & $\begin{array}{c}\text { Bobot Minimum } \\
\text { Algoritma } \\
\text { MST }(\mathrm{m})\end{array}$ & $\begin{array}{c}\text { Referensi } \\
\text { (pengukuran } \\
\text { Manual) }(\mathrm{m})\end{array}$ & $\begin{array}{c}\text { Kesalaha } \\
\mathrm{n}(\%)\end{array}$ \\
\hline $\mathrm{IV}$ & 3100,76 & 3095,43 & 0,172 \\
$\mathrm{~V}$ & 1107,81 & 1101,23 & 0,597 \\
\hline
\end{tabular}

Berdasarkan Tabel 2. terlihat bahwa kesalahan (error) data terhadap referensi (pengukuran manual) tidak melebihi 1\%. Ratarata kesalahan untuk bobot minimum yang dihasilkan algoritma MST adalah sebesar $0,384 \%$. Hal ini mengindikaskan bahwa bobot minimum yang dihasilkan algoritma MST untuk menentukan pohon rentang minimum jaringan listrik distribusi primer sudah hampir mendekati panjang kabel sebenarnya, meskipun belum $100 \%$ akurat.

Selanjutnya adalah pengujian bagian ketiga yang merupakan pengujian keenam. Tujuan dilakukan pengujian keenam ini adalah untuk 
mengetahui bobot minimum yang dihasilkan dari setiap feeder yang ada di wilayah PT. PLN Rayon Kota Bontang berupa panjang kabel jaringan listrik distribusi primer. Data bobot minimum yang dihasilkan dari algortima MST dipergunakan untuk mencari penurunan tegangan (drop voltage) dari masing-masing feeder di wilayah PT. PLN Rayon Kota Bontang. Dengan menggunakan data primer yang diperoleh dari PT. PLN Rayon Kota Bontang dan data pada Tabel 2, maka diperoleh data Tabel 3. sebagai berikut:

Tabel 3. Perbandingan data pengujian 6 dan data PT. PLN Rayon Kota Bontang

\begin{tabular}{cccc}
\hline $\begin{array}{c}\text { Feed } \\
\text { er }\end{array}$ & $\begin{array}{c}\text { Algoritma MST } \\
\text { Bobot Minimum } \\
(\mathrm{km})\end{array}$ & $\begin{array}{c}\text { PT. PLN } \\
\text { Rayon Kota } \\
\text { Bontang } \\
\text { Jarak dari GI } \\
(\mathrm{km})\end{array}$ & $\begin{array}{c}\text { Kesal } \\
\text { ahan } \\
(\%)\end{array}$ \\
\hline 1 & 30,561 & 28,114 & 0,087 \\
2 & 18,165 & 16,255 & 0,118 \\
3 & 15,321 & 13,172 & 0,163 \\
4 & 41,205 & 39,328 & 0,048 \\
5 & 27,212 & 23,331 & 0,166 \\
\hline
\end{tabular}

Berdasarkan data pada Tabel 2. dan Tabel 3. terlihat bahwa semakin besar bobot minimum yang dihasilkan oleh algoritma MST, maka waktu yang dibutuhkan untuk melakukan komputasi juga semakin lama. Hal ini disebabkan banyaknya data tiang yang harus dikerjakan algoritma MST untuk membentuk pohon rentang minimum. Disamping itu bobot minimum yang dihasilkan oleh algortima MST memiliki tingkat kesalahan yang relatif masih dibawah $1 \%$, dan rata-rata kesalahan yang dihasilkan dari algoritma MST ini adalah $0.1164 \%$.

Mengacu pada data primer PT.PLN Rayon Kota Bontang, diperoleh beberapa data untuk setiap feeder dengan beberapa ketetapan yang harus diberikan. Berikut rincian data pada setiap feeder ditunjukkan pada tabel 4 .
Tabel 4. Rincian Data pada Setiap Feeder dengan Tegangan Sumber $20 \mathrm{kV}$, Jenis

Penghantar A3C, dan Luas Penampang 150 $\mathrm{mm}^{2}$

\begin{tabular}{ccc}
\hline Feeder & $\begin{array}{c}\text { Tahanan Jenis } \\
\text { (ohm-mm) }\end{array}$ & $\begin{array}{c}\text { Arus Nominal } \\
\text { (A) }\end{array}$ \\
\hline 1 & 0,0286 & 259 \\
2 & 0,0286 & 231 \\
3 & 0,0286 & 289 \\
4 & 0,0286 & 231 \\
5 & 0,0286 & 144 \\
\hline & Sumber PT. PLN Rayon Kota Bontang
\end{tabular}

Berdasarkan data pada Tabel 2. dan Tabel 4. disertai dengan rumus penurunan tegangan pada persamaan (ii), (iii), serta (iv), maka akan dihasilkan penurunan tegangan pada masingmasing feeder di wilayah PT. PLN Rayon Kota Bontang. Rincian tentang penurunan tegangan pada setiap feeder ditunjukkan pada tabel 5.

Tabel 5. Penurunan pada Setiap Feeder

\begin{tabular}{|c|c|c|c|c|c|}
\hline \multirow[t]{4}{*}{$\begin{array}{l}\text { Fee } \\
\text { der }\end{array}$} & \multicolumn{3}{|c|}{ Algoritma MST } & \multicolumn{2}{|c|}{$\begin{array}{l}\text { PT. PLN Rayon } \\
\text { Kota Bontang }\end{array}$} \\
\hline & Bobot & Teg. & Drop & Jarak & Teg. \\
\hline & Mimimu & Ujung & Volta & dari GI & Ujung \\
\hline & $\mathrm{m}(\mathrm{km})$ & $\begin{array}{c}\text { Peneri } \\
\text { ma } \\
(\mathrm{kV})\end{array}$ & $\begin{array}{l}\text { ge } \\
(\%)\end{array}$ & $(\mathrm{km})$ & $\begin{array}{c}\text { Peneri } \\
\text { ma } \\
(\mathrm{kV})\end{array}$ \\
\hline 1 & 30,561 & 17,154 & 14,24 & 28,114 & 20,5 \\
\hline 2 & 18,165 & 18,628 & 6,86 & 16,255 & 20,5 \\
\hline 3 & 15,321 & 18,552 & 7,24 & 13,172 & 20,2 \\
\hline 4 & 41,205 & 16,887 & 15,56 & 39,328 & 20,4 \\
\hline 5 & 27,212 & 18,718 & 6,41 & 23,331 & 20,5 \\
\hline
\end{tabular}

Dari Tabel 5. terlihat penurunan tegangan terjadi dimasing-masing feeder. Penurunan tegangan terbesar terjadi pada feeder 4 yaitu sebesar $15,56 \%$, dan penurunan tegangan terkecil terjadi pada feeder 5 yaitu sebesar $6,41 \%$. Hal ini mengindikasikan bahwa semakin besar bobot minimum yang dihasilkan oleh algortima MST dalam hal ini panjang kabel/penghantar jaringan listrik distribusi primer, maka penurunan tegangan (drop voltage) pada jaringan juga akan semakin besar.

Secara umum drop voltage terjadi akibar dari beberapa faktor, antara lain:
a. Umur penghantar
b. Perbedaan kualitas penghantar
c. Adanya sambungan kabel
d. Impedansi dan admitansi saluran 
e. Beban dan faktor daya

Dengan membandingkan hasil perhitungan dengan data yang diperoleh dari PT. PLN Rayon Kota Bontang, terdapat kesalahan (error) data pada tegangan penerimaan ujung jaringan feeder. Kesalahan tersebut diakibatkan oleh adanya pengaruh hambatan (R) yang berasal dari penggunaan panjang pendeknya kabel jaringan listrik distribusi primer.

\section{KESIMPULAN}

Berdasarkan pencapaian terhadap hasil yang dicapai ada beberapa kesimpulan yang perlu diperhatikan, diantaranya:

1. Penentuan penurunan tegangan (drop voltage) pada suatu jaringan listrik distribusi primer dapat memanfaatkan bobot minimum yang dihasilkan dari algortima MST (minimum spanning tree) berupa panjang kabel atau penghantar jaringan distibusi listrik JTM.

2. Bobot minimum yang dihasilkan algoritma MST dapat mempengaruhi penurunan tegangan pada jaringan listrik distribusi primer di wilayah Kota Bontang rata-rata sebesare $10,062 \%$ dari tegangan sumber.

\section{DAFTAR PUSTAKA}

Bader, David. A (1999). Fast Shared- Memory Algorithms for Computing Minimum
Spanning Forest of Sparse Graphs, http://www.ece.unm.edu.

Johnson, D.E, Hilburn, J.L, and Johnson, J.R, (1992), Electric Circuit Analysis, Second Edition, Prentice-Hall, Inc., Nee Jersey.

Nugraha, Deny W, (2010), Pengkajian Kompleksitas Waktu Implementasi Algoritma MST (Studi Kasus Pada Jaringan Distribusi Listrik Primer di Wilayah Kota Palu), Tesis Program Studi Teknik Elektro, Universitas Gadjah Mada, Yogyakarta

Pop, P. C., Zelina, I., (2004), Heuristic Algorithms for the Generalized Minimum Spanning Tree Problem, http://emis.library.cornell.edu/ journals/AUA/acta8/Pop_Zelina.pdf, Proceedings of the International Conference on Theory and Applications of Mathematics and Informatics (ICTAMI), Thessaloniki, Greece, [19 Maret 2010].

Sukojo, B.M, Awalin,L.J, (2003), Pemanfaatan Analisa Sistem Informasi Geografis Distribusi Jaringan Listrik, Makara Teknologi, Vol.7 No.1, Surabaya. 